\title{
Interferons lambda, new cytokines with antiviral activity
}

\author{
K. LOPUŠNÁ ${ }^{3}$, I. REŽUCHOVÁ ${ }^{1}$, T. BETÁKOVÁ ${ }^{1,2}$, L. ŠKORVANOVÁ ${ }^{1}$, J. TOMÁŠKOVÁ ${ }^{1}$, L. LUKÁČIKOVÁ ${ }^{1}$, \\ P. KABÁT $T^{1,3^{*}}$
}

\begin{abstract}
${ }^{1}$ Institute of Virology, Slovak Academy of Sciences, Dúbravská cesta 9, 84505 Bratislava, Slovak Republic; ${ }^{2}$ Center for Molecular Medicine, Bratislava, Slovak Republic; ${ }^{3}$ Department of Microbiology and Virology, Comenius University Bratislava, Slovak Republic

Summary. - Interferons (IFNs) are key cytokines in the establishment of a multifaceted antiviral response. Three distinct types of IFNs are now recognized (type I, type II, and type III) based on their receptor usage, structural features and biological activities. Although all IFNs are important mediators of antiviral protection, their roles in antiviral defence vary. Interferon lambda (IFN- $\lambda$ ) is a recently discovered group of small helical cytokines capable of inducing an antiviral response both in vitro as well as in vivo. They were discovered independently in 2003 by the groups of Sheppard and Kotenko. This family consists of three structurally related IFN- $\lambda$ subtypes called IFN- $\lambda 1$ (IL-29), IFN- $\lambda 2$ (IL-28A), and IFN- $\lambda 3$ (IL-28B). In this study we investigate the antiviral activities of IFN- $\lambda 1, \lambda 2$, and $\lambda 3$ on some medically important viruses, influenza viruses, herpes viruses and lymphocytic choriomeningitis virus.
\end{abstract}

Keywords: interferon lambda; cytokines; influenza virus; herpes virus; lymphocytic choriomeningitis virus

\section{Contents:}

1. Cytokines of class II

1.1 Type I IFN

1.2 Type II IFN

1.3 Type III IFN

2. Structure of type III IFNs

3. Type III IFNs receptors

4. Regulation of type III IFNs synthesis and Jak-STAT signal transduction cascade

5. Biological activities

6. Interferons and arenaviruses

7. Interferons and herpes viruses

8. Interferons and influenza viruses

${ }^{\star}$ Corresponding author. E-mail: virupepo@savba.sk; +4212-54773172.

Abbreviations: DCs = dendritic cells; $\mathrm{H}=$ hemagglutinin; HHV-1, 2 = human herpesvirus 1, 2; IAV = influenza A virus; ICD = intracytoplasmatic domain; IFN(s) = interferon(s); IFNAR = IFN alpha receptor; $\mathrm{IFNGR}=\mathrm{IFN}$ gamma receptor; $\mathrm{IRF}=\mathrm{IFN}$ regulatory factor; ISGF = IFN stimulated gene factor; IL = interleukin; LCMV = lymphocytic choriomeningitis virus; $\mathrm{mDC}=$ monocyte-derived dendritic cells; $\mathrm{N}$ = neuraminidase; $\mathrm{PKR}=$ protein kinase $\mathrm{R}$

\section{Cytokines of class II}

\subsection{Type I IFN}

Type I IFN, which was discovered by Isaacs and Lindemann (1957), is a large family of cytokines (Peng et al., 2008). Type I IFNs are classified as $\alpha, \beta, \omega, \kappa, \varepsilon, \tau, \zeta, \delta$, and $v$ subtypes (Uzé and Monneron, 2007). They represent the first line of defence against many types of viral infections. Virus-infected cells synthesize and secrete type I IFNs, which act in both autocrine and paracrine fashions to induce an antiviral state in host cells. (Peng et al., 2008).

The type I IFNs exert their biological activities through a heterodimeric receptor complex composed of the IFNAR1 and IFNAR2 chains (Donnelly and Kotenko, 2010) and expressed on a wide variety of cell types (Perry et al., 2005). The type I IFNs activate a common signalling pathway leading to the activation of a set of genes controlled by the interferon stimulated gene factor (ISGF) (Uzé and Monneron, 2007). The gene products are involved in apoptosis, anti-growth, and innate and adaptive immune cell activation. Some of the most well-studied antiviral genes induced by type I IFNs include adenosine deaminase acting on RNA, $2^{\prime}, 5^{\prime}$-oligoadenylate synthetase, RNase L and Mx proteins. Adenosine deaminase acting on RNA leads to inhibition of 
translation initiation and RNA editing. 2 ', 5 ' -oligoadenylate synthetase is a dsRNA-dependent synthetase that activates the endoribonuclease RNase L to degrade ssRNA. Mx proteins are dynamic superfamily GTPases that act by binding target viral proteins to inhibit virus replication (Perry et al., 2005).

Type I IFN is primarily used against hepatitis $\mathrm{C}$ virus. However, hepatitis $\mathrm{C}$ virus resistance to IFN is prominent, likely due to mutations in the NS5A protein which inhibit Jak-STAT signalling pathway (Perry et al., 2005).

Type I IFNs are recognized also for their antitumour activity. IFN- $\alpha$ is used in the treatment of various cancers, including hairy cell and myelogenous leukaemias, multiple myeloma, non Hodgkin's lymphoma, renal cell carcinoma, Kaposi's sarcoma and metastatic melanoma (Donnelly and Kotenko, 2010).

\subsection{Type II IFN}

Type II IFN group consists only of IFN- $\gamma$ (Pitha, 2007), which is mainly secreted by $\mathrm{T}$ lymphocytes, natural killer cells (Peng et al., 2008) and antigen presenting cells (APCs) such as monocytes, macrophages and dendritic cells. IFN- $\gamma$ secretion by natural killer cells and professional antigen presenting cells is likely to be important in early host defence against infection, whereas T lymphocytes become the major source of IFN- $\gamma$ in the adaptive immune response. IFN- $\gamma$ production is controlled by cytokines secreted by antigen presenting cells, most notably interleukin (IL) 12 and 18. Macrophage recognition of many pathogens induces secretion of IL-12 and chemokines. These chemokines attract natural killer cells to the site of inflammation, and IL-12 promotes IFN- $\gamma$ synthesis in these cells (Schroder et al., 2004).

Although the tertiary structure of IFN- $\gamma$ resembles that of IL-10, its primary structure has diverged the most from all of the class II cytokine receptor family ligands (Donnelly and Kotenko, 2010). Functional IFN- $\gamma$ receptor (IFNGR) is comprised of two ligand-binding IFNGR1 chains associated with two signal-transducing IFNGR2 chains and associated signalling machinery (Schroder et al., 2004).

IFN- $\gamma$-induced antiviral mechanisms include induction antiviral enzymes, most notably protein kinase R (PKR), which is greatly induced by types I and II IFN stimulation. $\mathrm{PKR}$ is inactive in its constitutive form and requires an activating signal for autophosphorylation. An intermediate in replication of RNA viruses, dsRNA, is the best characterized activator of PKR, although other agents such as heparin are able to activate PKR. Association of PKR with dsRNA cause a conformational change that unmasks the catalytic domain responsible for PKR autophosphorylation. PKR is then activated for dsRNA-independent phosphorylation of specific cellular substrates (Schroder et al., 2004).
IFN- $\gamma$ can amplify the induction of antiviral activity by IFN- $\alpha$ or IFN- $\beta$. Type I and type II IFNs often work together to activate a variety of innate and adaptive immune responses (Donnelly and Kotenko, 2010).

IFN- $\gamma$ treatment can reduce viral titers in infected neuronal cells in vitro up to 100 -fold compared with untreated cells demonstrating its potent antiviral activity. This effect is not restricted solely to Vesicular stomatitis virus but can be demonstrated in central nervous system infections with other viruses including Sindbis virus, polio virus, influenza virus and measles virus. In the case of other viruses such as human herpesvirus 1 (HHV-1), IFN- $\gamma$ has been shown to limit transynaptic transmission, prevent viral reactivation and inhibit virally induced apoptosis (Chesler and Reiss, 2002).

IFN- $\gamma$ antiviral activity is not the primary biological function (Donnelly and Kotenko, 2010). IFN $\gamma$ plays a major role in regulating tumour development, not only by promoting protective host responses to tumours but also in orchestrating responses in tumours that facilitate their escape from immune attack (Ikeda et al., 2002).

\subsection{Type III IFN}

Type III IFNs are structurally and genetically distinct from type I IFNs and act through a distinct receptor system. However, they are identical in terms of mechanism of induction, signal transduction and biological activities (Uzé and Monneron, 2007). Phylogenetically the type III IFNs genes reside somewhere between the type I IFN and IL-10 gene families (Donnelly and Kotenko, 2010). At the amino acid level, type III IFNs are more closely related to type I IFNs than to IL-10 (Uzé and Monneron, 2007). The type III IFNs have 15-19\% amino acid sequence homology with the type I IFN families and 11-13\% amino acid sequence homology with the IL-10 (Hamming et al., 2010). However, the intron-exon structure of their genes resembles that of IL-10 and IL-10 related cytokines. Type III IFNs represent the ancestral IFN that gave rise to intronless type I IFNs by a retroposition event and successive duplications (Uzé and Monneron, 2007).

There are three IFN- $\lambda$ genes clustered on human chromosome 19. These genes have several exons, five for IFN- $\lambda 1$ (IL-29) and six for IFN- $\lambda 2$ (IL-28A) and IFN- $\lambda 3$ (IL-28B) (Uzé and Monneron, 2007), which is transcribed in the opposite direction of the IFN- $\lambda 1$ and IFN- $\lambda 2$ genes (Donnelly and Kotenko, 2010). In addition to the three functional genes, the human genome contains an additional pseudogene, IFN- $\lambda 4 \Psi$ (Hamming et al., 2010).

Although the intron sizes vary significantly, the exon sizes, positions and frames of the intron/exon junctions are highly conserved within the genes for the type III IFNs and the IL-10 related cytokines (Donnelly and Kotenko, 2010). 
In contrast, the type I IFNs have no introns (Hamming et al., 2010). The exons encode $20 \mathrm{kDa}$ secreted monomeric proteins. Only IFN- $\lambda 1$ contains a potential N-linked glycosylation site (Uzé and Monneron, 2007). At the amino acid level IFN- $\lambda 2$ and IFN- $\lambda 3$ are highly similar having $96 \%$ sequence identity while IFN- $\lambda 1$ shares approximately $81 \%$ sequence identity with IFN- $\lambda 2$ and IFN- $\lambda 3$ (Hamming et al., 2010).

The high degree of homology between the IFN- $\lambda$ genes suggests that these genes evolved from a common ancestor relatively recently. The promoters of the IFN- $\lambda 2$ and IFN- $\lambda 3$ genes are very similar and share several common elements with the IFN- $\lambda 1$ promoter, suggesting that all 3 genes are likely to be regulated in a similar manner. There are potential biding sites for a variety of transcription factors, including AP1 (dimeric transcription factor containing members of the Jun, Fos and activating transcription factor families) and nuclear factor- $\kappa \mathrm{B}$, as well as multiple virus response elements that provide the binding sites for various interferon regulatory factor (IRF) (Donnelly and Kotenko, 2010).

\section{Structure of type III IFNs}

Class II cytokines consist of six distinct structural elements (A-F) connected by loops of varying length (Fig. 1). In type III IFNs, $\alpha$-helices A, C, D, and F form a four helical bundle which constitutes the core of the structure, $\alpha$-helix $\mathrm{E}$ is relatively short and placed between element (loop) B and helix C, $a$-helix F distinguishes type I IFNs from the remaining members of the class II cytokines. In type I IFNs, this $a$-helix is straight whereas it contains a characteristic bend in the 3-D structure of IL-10, IL-19, IL-22, and IFN- $\gamma$. IFN- $\lambda 3$ (Protein Data Bank entry code: $3 \mathrm{HHC}$ ) forms monomeric structure with a bend in $\alpha$-helix F. Type III IFNs and type I IFNs are roughly the same size and have the same composition as secondary structural elements (Hamming et al., 2010).

IFN- $\lambda 1$ has three disulfide bonds with five cysteines in each bond whereas IFN- $\lambda 2$ and IFN- $\lambda 3$ have three disulfide bonds with seven cysteines in each bond. In IFN- $\lambda 3$, one bond connects the N-terminal region to the end of helix D. This bond appears conserved in all class II cytokines except IFN- $\gamma$, IFN- $\beta$, and IFN- $\varepsilon$. Another bond connects the ABloop to the beginning of $\alpha$-helix $\mathrm{F}$, this bond is not present in the class II cytokines. The final bond forms a small loop at the $\mathrm{C}$-terminal end of the protein. The first two bonds are present in IFN- $\lambda$ whereas the last bond is unique to IFN $-\lambda 2$ and IFN- $\lambda 3$ (Hamming et al., 2010).

$\alpha$-helices $\mathrm{A}$ and $\mathrm{F}$ form the major site of interaction with IFN- $\lambda$ R 1 and IL-10R 2 chain binds to helices $A$ and $D$ at an area adjacent to the IFN- $\lambda \mathrm{R} 1$ binding region (Gad et al., 2009).

\section{Type III IFNs receptors}

Type III IFNs act through a cell surface receptor composed of two chains, the first one (IFN- $\lambda$ R1) (Uzé and Monneron, 2007) also known as IL-28RA being IFN- $\lambda$ specific and the second one, IL10R2 shared among IL-10, IL-22, and IL-26. The genes encoding the IFN- $\lambda$ receptor subunits are located on human chromosome 1 (1p36.11 region), in close proximity to the gene encoding the receptor of IL-22R1, and chromosome 21 (21q22.11 region) (Donnelly and Kotenko, 2010). Both type III IFNs receptor chains consist of an extracellular, a transmembrane and an intracellular part. The extracellular part has two type III fibronectin domains. Each of the type III fibronectine domains consist of around 100 amino acids that form two antiparallel $\beta$-sheets making a sandwich consisting of approximately seven strands. The two fibronectin domains are connected by a short linker of 5-10 amino acids allowing for flexibility between the two domains. The transmembrane part is a highly lipophilic stretch of about 20-25 amino acids predicted to form an $\alpha$-helix (Hamming et al., 2010).

IFN- $\lambda \mathrm{R} 1$ gene encodes a receptor with an extracellular domain of about 200 amino acids, a single transmembrane domain and a cytoplasmic part of 223 amino acids. Because of the seven exons structure of the IFN- $\lambda$ R 1 gene, as well as the predicted three-dimensional structure of its ectodomain and the position of conserved cysteine, IFN- $\lambda \mathrm{R} 1$ is put into the class II cytokine receptor family including the chain building receptors for IL-10, IL-19, IL-20, IL-22, IL-24, IL-26 type I IFNs, and IFN- $\gamma$. The first alternatively spliced variant of IFN- $\lambda$ R1 mRNA encodes a receptor carrying a deletion of 29 amino acids in its intracytoplasmatic domain (ICD), which is likely devoid of signalling ability. The second one encodes the ectodomain which is likely secreted and soluble (Uzé and Monneron, 2007).

While the receptor for type I IFN is ubiquitously expressed, the IFN- $\lambda \mathrm{R} 1$ component of the type III IFN receptor is only present on a distinct subset of cells (Hamming et al., 2010). The mRNA encoding IFN- $\lambda \mathrm{R} 1$ is undetectable in several cell types, mainly fibroblastic and endothelial cells which are therefore unresponsive to type III IFNs. IFN- $\lambda$ R 1 is also expressed in cell lines derived from various tumours, including liver, colorectal and pancreatic carcinomas, but not or at very low levels in the fibrosarcoma HT1080 and kidney carcinoma HEK-293 cell lines (Uzé and Monneron, 2007).

The IFN- $\lambda \mathrm{R} 1$ is assumed to provide the majority of binding energy but interaction with the IL-10R2 is required for proper signal transduction (Gad et al., 2009). Although type III IFNs do not use the IFN-a receptor complex for signalling, signalling through IFN- $\lambda$ or IFN- $\alpha$ receptor complexes results in the activation of the same Jak-STAT signal transduction cascade (Donnelly and Kotenko, 2010). 


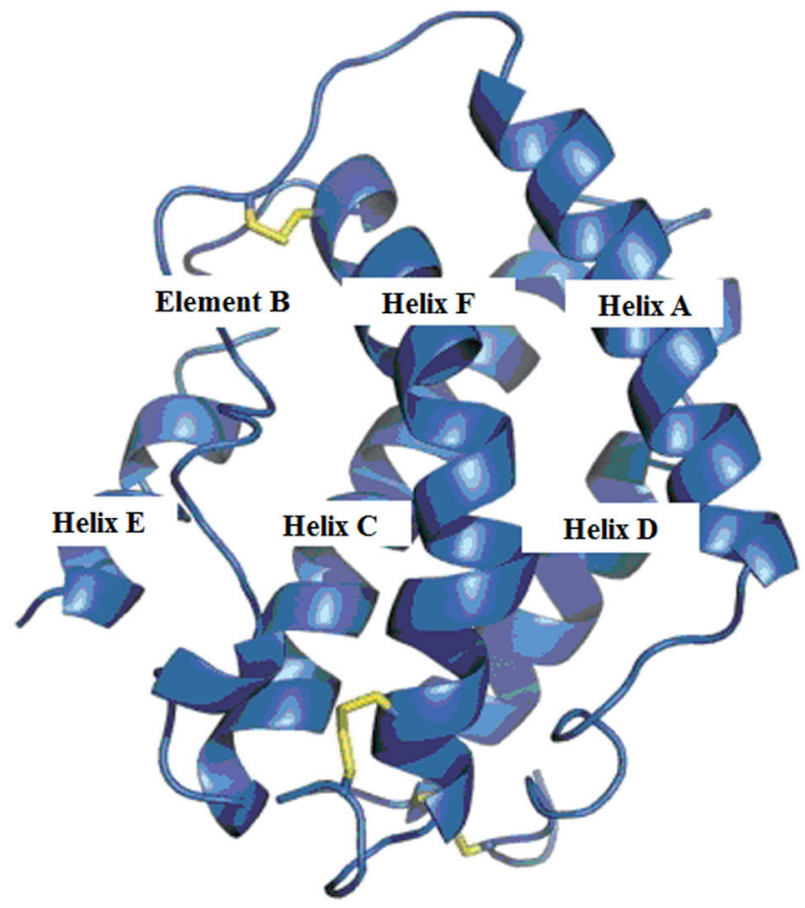

Fig. 1

The structure of human IFN- $\lambda$

Disulfide bonds are in yellow (Hamming et al., 2010).
Human blood immune cells also synthesize an IFN- $\lambda$ R 1 variant lacking the intracellular and transmembrane parts through alternative splicing. This receptor is also called soluble IFN- $\lambda \mathrm{R} 1$ and acts as a decoy by binding type III IFNs and as a repressor of type III IFNs signalling in vitro (Witte et al., 2009).

\section{Regulation of type III IFNs synthesis and Jak-STAT signal transduction cascade}

Type III IFN gene regulation does not look too different from type I induction. Viral infection leads to activation of interferon regulatory factors (IRF) IRF3, IRF7, and nuclear factor- $\kappa$ B. IRF3 and IRF7 induce the production of IFN- $\lambda 1$, activation of IRF7 induces the production of IFN- $\lambda 2$ and IFN- $\lambda 3$. Binding sites for nuclear factor- $\kappa \mathrm{B}$ are also found in type III IFN promoters (Hamming et al., 2010).

Binding of IFN- $\lambda 1$, IFN- $\lambda 2$ or IFN- $\lambda 3$ to the membraneassociated type III IFN receptor complex leads to the activation of the Janus kinases, Jak1 and Tyk2 (Fig. 2) (Donnelly and Kotenko, 2010) The two kinases cross-phosphorylate and thus activate one another. This leads to the tyrosine phosphorylation of the three tyrosine residues IFN- $\lambda \mathrm{R} 1$ ICD: Tyr406 and Tyr343, Tyr517 which are important for

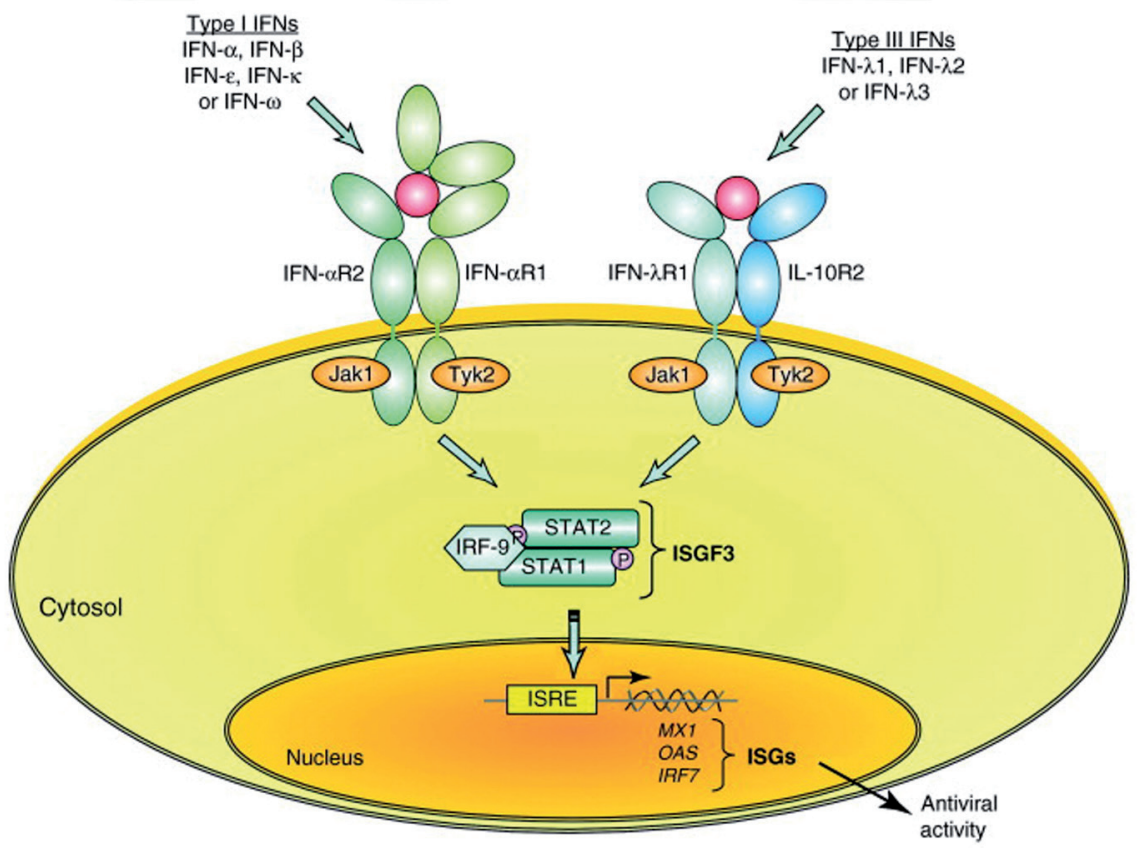

Fig. 2

Binding of IFN- $\alpha$ to the type I interferon receptor (IFNAR1 and IFNAR2) and IFN- $\lambda$ to the type III interferon receptor complex (IFN- $\lambda$ R1 and IL-10R2) activates the JAK1 and TYK2

These cross phosphorylate one another and activate the kinases leading to phosphorylation of STAT1 and STAT2 that form a heterodimer. The dimer binds IRF9 forming the ISGF3 complex that migrates to the nucleus where it binds to IFN-stimulated response elements and facilitates the transcription of interferon-stimulated genes (Donnely et al., 2011). 
antiviral activity as they create a docking site for the Src Homology 2 domain of the transcription factor STAT2 (Hamming et al., 2010). Activation (phosphorylation) of STAT1, STAT3 and STAT4 occurs independently of the tyrosine residues on the ICD of IFN- $\lambda$ R1 (Donnelly and Kotenko, 2010).

The activated STATs are tyrosine-phosphorylated towards the C-terminal end of the STAT proteins which serve as docking sites for the Src Homology 2 domains of the STAT proteins allowing for formation of homo- and heterodimers (Hamming et al., 2010). The STAT homo- and heterodimers translocate to the nucleus where they bind to specific DNA elements such as IFN- $\gamma$ activated sequence (GAS) elements in the promoters of IFN-responsive genes and modulate their transcription. Activated STAT1 and STAT2 molecules recruit IRF-9 to form a trimeric transcription factor complex known as ISGF3 (Interferon-stimulated gene factor) (Donnelly and Kotenko, 2010), which can also be activated by type I IFN. This complex appears to be the main driving force of type III IFN gene activation (Zhou et al., 2007) and regulates gene transcription by binding to IFN-stimulated response elements in the promoters of other interferon-stimulated genes. These include a number of genes that are classically associated with the antiviral phenotype, including OAS1, MX1, EIF2AK2, and IRF7. The repertoire of genes that are induced by type III IFNs is essentially the same as those which are induced by type I IFNs (Donnelly and Kotenko, 2010).

\section{Biological activities}

All type III IFNs subtypes are produced upon infection of HeLa, HuH7 or HT29 cell lines by Sindbis virus, Dengue virus, Vesicular stomatitis virus or Encephalomyocarditis virus. Also, stimulation of Toll-like receptor 3 with double stranded RNA initiates type III IFNs production in peripheral blood mononuclear cell (Kotenko et al., 2003, Sheppard et al., 2003). Several other viruses, including human herpesvirus 1 and 2 (HHV-1, HHV-2), influenza A virus (IAV), measles virus, BK virus, mumps virus and respiratory syncytial virus induce IFN- $\lambda$ in lymphoid, myeloid or epithelial cell lines (Donnelly and Kotenko, 2010).

Type III IFNs are coexpressed together with type I IFNs by virus-infected cells, which is consistent with the existence of common upstream regulatory elements in the IFN- $\alpha$ and IFN- $\lambda$ genes (Donnelly and Kotenko, 2010). Type I and type III interferons contribute the first line of antiviral defence in epithelial tissues, which often suffer high risk of viral infection (Hamming et al., 2010). Infection by live viruses induces coexpression of IFN- $\alpha$, IFN- $\beta$, and IFN- $\lambda$, whereas other microbial agents or their structural components such as bacterial DNA, endotoxin and double-stranded RNA induce a more selective expression of the IFN subtypes. IFN- $\alpha / \beta$ and IFN- $\lambda$ ligand-receptor systems are activated independently in response to viral infections. Inhibition of signalling through type I IFN receptors with neutralizing anti-IFNAR antibodies does not block signalling through type III IFN receptors (Donnelly and Kotenko, 2010).

In addition to its role in innate immunity, type III IFNs are also capable of modulating the adaptive immune response. During differentiation, dendritic cells (DCs) begin expressing the IFN- $\lambda \mathrm{R} 1$ receptor and thus respond to IFN- $\lambda$. IFN- $\lambda$ stimulated DCs are CD80 and CD40 low but have increased levels of major histocompatibility complex class I, II and the chemokine receptor CCR7 important for migration of DCs. These DCs migrate to lymph nodes and the spleen where they induce regulatory Foxp3+CD25+CD4+ T-cell proliferation in the spleen. These regulatory T-cells are known to be able to repress T-cell proliferation which is important for normal immunohomeostasis and negative regulation of the immune response (Hamming et al., 2010).

Type III IFNs inhibit hepatitis B virus replication in a differentiated murine hepatocyte cell line and replication of subgenomic and full-length hepatitis $\mathrm{C}$ virus replicons in the human hepatoma cell line, Huh7 (Robek et al., 2005). Influenza virus and Sendai virus have also been shown to induce expression of type III IFNs in human monocytederived dendritic cells (Donnelly and Kotenko, 2010).

Type III IFNs are potent antiviral cytokines in vivo and target epithelial cells to induce antiviral activity (Hamming et al., 2010). Recent studies have shown that local administration of recombinant IFN- $\lambda$ to mice potently inhibited replication of HHV-1, HHV-2, and IAV in the vagina and lungs (Mordstein et al., 2008; Ank et al., 2006).

Type III IFNs also induce expression of double stranded RNA-activated protein kinase $2^{\prime}, 5^{\prime}$-oligoadenylate synthetase, which is one of the classic biomarkers of the antiviral response. Type III IFNs can significantly up-regulate expression of the cytokine signalling inhibitory gene, suppressor of cytokine signaling SOCS3, suggesting a possible mechanism for feedback inhibition of IFN- $\lambda$ signalling (Donnelly and Kotenko, 2010).

The antiproliferative and apoptotic effects of type III interferon have been shown in vitro (Maher et al., 2008; Li et al., 2008). Although type I IFNs are able to induce antiproliferative responses in many cell types, the antiproliferative activity of type III IFNs is more limited (Maher et al., 2008). This activity depends on the relative levels of IFN- $\lambda$ R1 expression because type III IFNs can effectively inhibit proliferation cells engineered to express high levels of IFN- $\lambda$ R1 by forced expression of an IFN- $\lambda \mathrm{R} 1$ expression plasmid or a chimeric receptor that recapitulates IFN- $\lambda$ signalling in cells (Miller et al., 2009).

The side effect profile of type III IFNs over type I IFN was demonstrated in a phase I study of the effect of type III IFNs against hepatitis $C$ virus. While some of the patients 
treated with type I IFN developed neutropenia or anaemia, patients treated with type III IFNs remained symptom free (Miller et al., 2009).

\section{Interferons and arenaviruses}

Arenaviruses represent a large family of viruses, which merit attention as powerful model systems for experimental virology and as important human pathogens. They are enveloped viruses with a bisegmented negative-strand RNA and a nonlytic life cycle restricted to the cell cytoplasm. Each genomic segment uses an ambisense coding strategy to direct the synthesis of two polypeptides from two opposite open reading frames separated by an intergenic region. The small (S) segment encodes a major viral protein nucleoprotein (NP) and a glycoprotein precursor, which is posttranslationally cleaved into a peripheral glycoprotein 1 GP1 and a transmembrane glycoprotein 2 GP2. The large (L) segment encodes a viral RNA-dependent RNA polymerase (L) and a small regulatory RING domain-containing $\mathrm{Z}$ protein $(\mathrm{Z})$ (Buchmeier et al., 2007; Welsh, 2008). The prototypic arenavirus lymphocytic choriomeningitis virus (LCMV) has been used in many studies that uncovered fundamental concepts in molecular virology, viral pathogenesis, viral immunology, viral persistence, and virus-host interactions (Buchmeier et al., 2007; Oldstone, 2002; Zinkernagel, 2002).

Arenaviruses cause chronic infections of rodent species with worldwide distribution. Human infections, which occur via mucosal exposure to aerosols or by direct contact with infectious materials, can cause severe diseases, including hemorrhagic fever. The most significant pathogen among the arenaviruses is Lassa virus, which causes several hundred thousand infections per year in Western Africa, with thousands of deaths (McCormick and Fisher-Hoch, 2002). Similarly, in South America, Junin virus, Machupo virus, Guanarito virus, and Sabia virus have emerged as causative agents of severe hemorrhagic fever disease (Peters, 2002). Moreover, increasing evidence indicates that LCMV is a neglected human pathogen of clinical significance in congenital infections (Barton and Mets, 1999; Barton et al., 2002; Barton et al., 1995; Mets et al., 2000), and also represents a serious problem to immunosuppressed individuals (Fischer et al., 2006; Palacios et al., 2008). Thus far, licensed vaccines against Lassa virus or LCMV are not available, and current antiarenavirus therapy is limited to the use of the nucleoside analog ribavirin, which is only partially effective and can cause significant side effects.

Arenavirus persistence and pathogenesis are believed to be facilitated by their ability to overcome the host innate immune system (McCormick and Fisher-Hoch, 2002). Chronic infection of the prototypic arenavirus LCMV in mice is associated with only a modest elevation in type I levels, despite widespread viral replication and high viral proteins (Saron et al., 1982), suggesting that the virus escapes innate detection and/or can efficiently counteract mechanisms of innate defence (Borrow et al., 2010). Accordingly, it was shown that the nucleoprotein of the LCMV counteracts type I IFN response during viral infection by inhibiting activation of IFN regulatory factor 3 (IFR3) and subsequent induction of type I IFN production and interferon-stimulated genes. This IFN-counteracting activity is highly conserved among arenaviruses (Martinez-Sobrido et al., 2007). These findings were further confirmed and extended by demonstrating that LCMV NP blocks type I IFN production through targeting both the MDA5- and RIG-I mediated signalling pathway (Zhou et al., 2010). Recently, it has been found that LCMV NP associated with the kinase domain of interferon regulatory factor-activating kinase IKKe and blocked its activity without undergoing phosphorylation (Pythoud et al., 2012). Moreover, it was shown that LCMV-NP, as well as NPs from other representative members within the Arenaviridae family also inhibit the nuclear translocation and transcriptional activity of the nuclear factor kappa $B$ (Rodrigo et al., 2012).

On the other hand, acute LCMV infection of mice is associated with rapid induction of a strong systemic type I IFN response (Malmgaard et al., 2002; Merigan et al., 1977), which promotes an effective innate and adaptive control of infection (Borrow et al., 2010; Kolumam et al., 2005; Muller et al., 1994). Virus is quickly cleared by virus-specific CD8+ cytotoxic $\mathrm{T}$ cells which receive help from IFN- $\gamma$-producing CD4+ T cells (Bevan, 2004).

Taken together, type I and II IFNs play a critical role in LCMV infection by reducing viral loads in the initial stages of infection, thus modifying both the extent of CD8+ T cell exhaustion and the course of infection (Ou et al., 2001).

However, there is very limited data regarding IFN- $\lambda \mathrm{s}$ signalling and antiviral properties in LCMV infection. Ank et al. demonstrated that IFN- $\lambda$ is unable to control systemic LCMV infection in mice (Ank et al., 2006, 2008) and therefore for such an infection the functional type I IFN antiviral system is required. However, there might be significant differences between mice and humans. The infection of mice with LCMV has been well characterized, but there is currently no data on responses in the initial stages of infection in humans.

\section{Interferons and herpes viruses}

Herpesviruses are enhanced all over the world. More than 100 herpesviruses have been isolated from mammals, birds, fish, reptiles and amphibians. Eight herpesviruses are human viruses. Herpesvirus infections are often latent infections which can be reactivated, especially if the host becomes 
immunocompromised. Primary and reactivated herpesvirus infections can be asymptomatic or can result in disease of varying severity (Carter and Saunders, 2007).

The herpesvirus genome is a linear dsDNA molecule, which varies in size from 125 to $240 \mathrm{kbp}$. The DNA is enveloped in the capsid of icosaedral symmetry, which contains 162 capsomeres, 12 capsomeres are pentons and 150 capsomeres are hexons. The capsid is surrounded by the tegument, which contains at least 15 proteins and virus mRNA molecules (Carter and Saunders, 2007).

Human herpesvirus 1 (HHV-1) belongs to the subfamily Alphaherpesvirinae, the family Herpesviridae (Farooq and Shukla, 2012). It is characterized by a short reproductive cycle and prompt destruction of the host cell (James et al., 2009). It initially infects epithelial cells of the oral mucosa, the skin or the cornea. HHV-1 may enter neurons and may be transported to their nuclei, where the viruses may establish latent infections. Reactivated virions are transported within the neuron to the initial site of infection where they cause productive infection in epithelial cells, resulting in a cold sore. There may be also serious complications such as encephalitis (Carter and Saunders, 2007), which are associated with significant morbidity and mortality in spite of antiviral therapy (James et al., 2009). Ocular HHV-1 manifests as conjunctivitis, acute retinal necrosis and keratitis. HHV-1 keratitis is an important cause of infectious blindness ( Farooq and Shukla, 2012).

It has been found that IFN- $\beta$ and IFN- $\gamma$ treatments synergistically inhibit HHV-1 replication in primary human fibroblast cells (Peng et al., 2008). Expression of interferon regulatory factor 1 is increased during all phases of herpesvirus infection. This gene is a member of the larger IRF family of transcription factors, which induce interferonstimulated genes in response to interferon signalling (Szpara et al., 2010).

It has also been examined the ability of type III IFNs to inhibit HHV-1 replication in astrocytes and neurons. Both IFN- $\lambda 1$ and IFN- $\lambda 2$ significantly inhibited HHV-1 glycoprotein D DNA synthesis in astrocytes without the toxicity to astrocytes and neurons (Li et al., 2011).

\section{Interferons and influenza viruses}

The Orthomyxoviridae family IAV is a common respiratory pathogen that can cause severe viral pneumonia with alveolar inflammation and infiltration of neutrophils and mononuclear cells (Yeldandi and Colby, 1994). The genome of IAV consists of 8 negative single-stranded RNA segments that encode 12 functional peptides necessary for viral replication and virulence (Wise et al., 2009). The main antigenic determinants of IAV are the hemagglutinin $(\mathrm{H})$ and neuraminidase $(\mathrm{N})$ transmembrane glycopro- teins. Based on the antigenicity of those glycoproteins, IAVs are further subdivided into $17 \mathrm{H}(\mathrm{H} 1$ to $\mathrm{H} 17)$ and $9 \mathrm{~N}$ (N1 to N9) subtypes (Tong et al., 2012). H1N1 and H3N2 subtypes are currently circulating in the human population.

Primary cellular targets of influenza infection are the epithelial cells of the upper respiratory tract. The virus is also capable of infecting other cell types such as $\mathrm{T}$ cells, monocytes/macrophages and dendritic cells. Each cell type has a unique response to virus infection (Ronni et al., 1995; Sareneva et al., 1998; Pirhonen et al., 1999; Julkunen et al., 2000). Interferons play a critical role in innate as well as in adaptive immune responses against viral infections (Alexopoulou et al., 2001; Au et al., 2001). IAV-infected epithelial cells produce limited amounts of the type I IFNs (IFN- $\alpha / \beta)$, proinflammatory cytokines IL-1, IL-6, and tumor necrosis factor alpha, chemokines RANTES, MCP, and IL-8 as well as the type III IFNs (Julkunen et al., 2000; Kotenko et al., 2003; Sheppard et al., 2003; Pestka et al., 2004). Macrophages produce significant levels of IFN- $\alpha / \beta$, IL-1ß, TNF- $\alpha$, chemokines, and IL-18 (Sareneva et al., 1998; Pirhonen et al., 1999, 2002; Matikainen et al., 2000). IAV-infected DCs, especially plasmacytoid DCs, produce high level of IFN- $\alpha / \beta$ (Cella et al., 2000; Coccia et al., 2004). IFN- $\alpha / \beta$ is involved in the development of Th1 immunity by stimulating natural killer and T-cell Th1 cytokine receptor gene expression and IFN- $\gamma$ production (Sareneva et al., 1998, 2000; Matikainen et al., 2001). IFN-a reduces virus replication and lowers host innate immune response following infection (Jiang et al., 2011).

IAVs can induce the expression of IFN- $\lambda 2$ and 3 as well as IFN- $\lambda 1$ genes whose gene products are likely to contribute to the host antiviral response. IFN- $\lambda 1$ exerts an antiviral effect during IAV infection through activation of antiviral genes and this antiviral effect is independent of IFN- $B$ (Osterlund et al., 2005; Wang et al., 2009). IFN- $\lambda 2$ and IFN- $\lambda 3$ inhibited replication of IAV in the cells treated with these IFNs (Svetlikova et al., 2010). Recombinant chicken IFN- $\lambda$ inhibited influenza virus replication and induced the mRNA expression of the interferon-stimulated genes, $\mathrm{Mx}$ and 2',5' -oligoadenylate synthetase, in chicken embryonic fibroblasts) in a dosedependent manner. The effective dose of IFN- $\lambda$ is higher than that of IFN- $\beta$ and IFN- $\gamma$. Furthermore, the effect of IFN- $\lambda$ on induction of $\mathrm{Mx}$ and $2^{\prime}, 5^{\prime}$-oligoadenylate synthetase is less than that of IFN- $\beta$, but comparable to that of IFN- $\gamma$ (Masuda et al., 2012). Induction of type I and type III IFN expression is specific for each IAV (Sutejo et al., 2012).

Acknowledgements. Testing of antiviral activities was supported by the VEGA-Scientific grant agency of the Ministry of Education of the Slovak Republic and of Slovak Academy of Sciences (grant Nos. VEGA 1/0265/11 and VEGA 2/0128/11). 


\section{References}

Alexopoulou L, Holt AC, Medzhitov R, Flavell RA, Nature 413, 732-738, 2001. http://dx.doi.org/10.1038/35099560

Ank N, Iversen MB, Bartholdy C, Staeheli P, Hartmann R, Jensen UB, Dagnaes-Hansen F, Thomsen AR, Chen Z, Haugen H, Klucher K, and Paludan SR, J. Immunol. 180, 2474-2485, 2008.

Ank N, West H, Bartholdy C, Eriksson K, Thomsen AR, Paludan SR, J. Virol. 80, 4501-4509, 2006. http://dx.doi.org/10.1128/ JVI.80.9.4501-4509.2006

Au WC, Yeow WS, Pitha PM, Virology 280, 273-282, 2001. http:// dx.doi.org/10.1006/viro.2000.0782

Barton LL, Mets MB, Pediatr. Infect. Dis. J. 18, 540-1, 1999. http:// dx.doi.org/10.1097/00006454-199906000-00013

Barton LL, Mets MB, Beauchamp CL, Am. J. Obstet. Gynecol. 187, 1715-1716, 2002. http://dx.doi.org/10.1067/ mob.2002.126297

Barton LL, Peters CJ, Ksiazek TG, Emerg. Infect. Dis. 1, 152-153, 1995. http://dx.doi.org/10.3201/eid0104.950410

Bergthaler A, Flatz L, Hegazy AN, Johnson S, Horvath E, Lohning M, Pinschewer DD, Proc. Natl. Acad. Sci. USA 107, $21641-$ 21646, 2010. http://dx.doi.org/10.1073/pnas.1011998107

Bevan MJ, Nat. Rev. Immunol. 4, 595-602, 2004. http://dx.doi. org/10.1038/nril413

Borrow P, Martinez-Sobrido L, de la Torre JC, Viruses 2, 2443-2480, 2010. http://dx.doi.org/10.3390/v2112443

Buchmeier MJ, de La Torre JC, Peters CJ, In Knipe, DM, Howley PM (Ed.): Fields Virology Lippincott Williams \& Wilkins, Philadelphia, 1793-1826, 2007.

Buchmeier MJ, Welsh RM, Dutko FJ, Oldstone MB, Adv. Immunol. 30, 275-331, 1980 http://dx.doi.org/10.1016/S00652776(08)60197-2

Carter JB, Saunders VA, John Wiley \& Sons Ltd. England, 122124. ISBN 978-0-470-02386-0, 2007 Cella M, Salio M, Sakakibara Y, Langen H, Julkunen I, Lanzavecchia A, J. Exp. Med. 189, 821-829, 1999. http://dx.doi.org/10.1084/ jem.189.5.821

Cella M, Facchetti F, Lanzavecchia A, Colonna M, Nat. Immunol. 1, 305-310, 2000. http://dx.doi.org/10.1038/79747

Cervantes-Barragan L, Lewis KL, Firner S, Thiel V, Hugues S, Reith W, Ludewig B, Reizis B, Proc. Natl. Acad. Sci. USA 109, 3012-30177, 2012. http://dx.doi.org/10.1073/ pnas. 1117359109

Chesler DA, Reiss CS, Cytokine Growth Factor Rev. 13, 441-454, 2002. http://dx.doi.org/10.1016/S1359-6101(02)00044-8

Coccia EM, Severa M, Giacomini E, Monneron D, Remoli ME, Julkunen I, Cella M, Lande R, Uzé G, Eur. J. Immunol. 34, 796-805, 2004. http://dx.doi.org/10.1002/eji.200324610

Donnelly RP, Kotenko SV, Interferon \& Cytokine Res. 30, 555-564, 2010. http://dx.doi.org/10.1089/jir.2010.0078

Donnelly RP, Dickensheets H, O'Brien TR, Trends Immunol. 32, 443-450, 2011.

Farooq AV, Shukla D, An Epidemiologic Update. Surv. Ophthalmol., 57, 448-462, 2012. http://dx.doi.org/10.1016/j.survophthal.2012.01.005

Fischer SA, Graham MB, Kuehnert MJ, Kotton CN, Srinivasan A, Marty FM, Comer JA, Guarner J, Paddock CD, DeMeo DL, Shieh WJ, Erickson BR, Bandy U, DeMaria AJr, Davis
JP, Delmonico FL, Pavlin B, Likos A, Vincent MJ, Sealy TK, Goldsmith CS, Jernigan DB, Rollin PE, Packard MM, Patel M, Rowland C, Helfand RF, Nichol ST, Fishman JA, Ksiazek T, Zaki SR, N. Engl. J. Med. 354, 2235-2249, 2006. http://dx.doi.org/10.1056/NEJMoa053240

Gad HH, Dellgren C, Hamming OJ, Vends S, Paludan SR, Hartmann R, J. Biol. Chem. 284, 20869-20875, 2009. http:// dx.doi.org/10.1074/jbc.M109.002923

Hamming OJ, Gad HH, Paludan S, Hartmann R, Pharmaceuticals 3, 795-809, 2010. http://dx.doi.org/10.3390/ph3040795

Hemmi H, Kaisho T, Takeuchi O, Sato S, Sanjo H, Hoshino K, Horiuchi T, Tomizawa $\mathrm{H}$, Takeda $\mathrm{K}$, Akira S, Nat. Immunol. 3, 196-200, 2002. http://dx.doi.org/10.1038/ni758

Ikeda H, Old LJ, Schreiber RD, Cytokine Growth Factor Rev. 13, 95-109, 2002. http://dx.doi.org/10.1016/S13596101(01)00038-7

Isaacs A, Lindemann J, Proc. R. Soc. Lond. B Biol. Sci. 147, 258-267, 1957. http://dx.doi.org/10.1098/rspb.1957.0048

James SH, Kimberlin DW, Whitley RJ, Antiviral Res. 83, 207-213, 2009. http://dx.doi.org/10.1016/j.antiviral.2009.04.010

Jiang H, Yang H, Kapczynski DR, Virol. J. 8, 447, 2011 http://dx.doi. org/10.1186/1743-422X-8-447

Julkunen I, Melén K, Nyqvist M, Pirhonen J, Sareneva T, Matikainen S, Vaccine 19, 32-37, 2000. http://dx.doi.org/10.1016/ S0264-410X(00)00275-9

Kim PS, Ahmed R, Curr. Opin. Immunol. 22, 223-30, 2010. http:// dx.doi.org/10.1016/j.coi.2010.02.005

Kolumam GA, Thomas S, Thompson LJ, Sprent J, Murali-Krishna K, J. Exp. Med. 202, 637-650, 2005. http://dx.doi. org/10.1084/jem.20050821

Kotenko SV, Gallagher G, Baurin VV, Lewis-Antes A, Shen M, Shah NK, Langer JA, Sheikh F, Dickensheets H, Donnelly RP, Nat. Immunol. 4, 69-77, 2003. http://dx.doi.org/10.1038/ni875

Li J, Hu S, Zhou L, Ye L, Wang X, Ho J, Ho W, Glia 59, 58-67, 2011. http://dx.doi.org/10.1002/glia.21076

Li W, Lewis-Antes A, Huang J, Balan M, Kotenko SV, Cell Prolif. 41, 960-979, 2008. http://dx.doi.org/10.1111/j.13652184.2008.00558.x

Maher SG, Sheikh F, Scarzello AJ, Romero-Weaver AL, Baker DP, Donelly RP, Gamero AM, Cancer Biol. Ther. 7, 1109-1115, 2008. http://dx.doi.org/10.4161/cbt.7.7.6192

Malmgaard L, Salazar-Mather TP, Lewis CA, Biron CA, J. Virol. 76, 4520-4525, 2002. http://dx.doi.org/10.1128/ JVI.76.9.4520-4525.2002

Martinez-Sobrido L, Zuniga EI, Rosario D, Garcia-Sastre A, de la Torre JC, J. Virol. 80, 9192-9199, 2006. http://dx.doi. org/10.1128/JVI.00555-06

Masuda Y, Matsuda A, Usui T, Sugai T, Asano A, Yamano Y, J. Vet. Med. Sci. 2012 (in press).

Matikainen S, Pirhonen J, Miettinen M, Lehtonen A, GoveniusVintola C, Sareneva, T, Julkunen I, Virology 276, 138-147, 2000. http://dx.doi.org/10.1006/viro.2000.0542

Matikainen S, Paananen A, Miettinen M, Kurimoto M, Timonen T, Julkunen I, Sareneva T, Eur. J. Immunol. 31, 2236-2245, 2001. http://dx.doi.org/10.1002/15214141(200107)31:7<2236::AID-IMMU2236>3.0.CO;2-G

McCormick JB, Fisher-Hoch SP, Curr. Microbiol. Immunol. 262, 75109, 2002. http://dx.doi.org/10.1007/978-3-642-56029-3 4 
Merigan TC, Oldstone MB, Welsh RM, Nature 268, 67-68, 1997. http://dx.doi.org/10.1038/268067a0

Mets MB, Barton LL, Khan AS, Ksiazek TG, Am. J. Ophthalmol. 130, 209-215, 2000. http://dx.doi.org/10.1016/S00029394(00)00570-5

Miller DM, Klucher KM, Freeman JA, Hausman DF, Fontana D, Williams DE, Ann. N. Y. Acad. Sci. 1182, 80-87, 2009. http://dx.doi.org/10.1111/j.1749-6632.2009.05241.x

Mordstein M, Kochs G, Dumoutier L, Renauld JC, Paludan SR, Klucher K, Staeheli P PLoS Pathog. 4, e1000151, 2008. http://dx.doi.org/10.1371/journal.ppat.1000151

Mordstein M, Neugebauer E, Ditt V, Jessen B, Rieger T, Falcone V, Sorgeloos F, Ehl S, Mayer D, Kochs G, Schwemmle M, Gunther S, Drosten C, Michiels T, Staeheli P, J. Virol. 84, 5670-5677, 2010. http://dx.doi.org/10.1128/JVI.00272-10

Muller U, Steinhoff U, Reis L F, Hemmi S, Pavlovic J, Zinkernagel RM, Aguet M, Science 264, 1918-1921, 1994. http:// dx.doi.org/10.1126/science. 8009221

Oldstone MB, Curr. Top. Microbiol. Immunol. 263, 83-117, 2002. http://dx.doi.org/10.1007/978-3-642-56055-2 6

Oldstone MB, PLoS Pathog 5, e1000523,2009. http://dx.doi. org/10.1371/journal.ppat.1000523

Osterlund P, Veckman V, Sirén J, Klucher KM, Hiscott J, Matikainen S, Julkunen I, J. Virol., 79, 9608-9617, 2005. http://dx.doi. org/10.1128/JVI.79.15.9608-9617.2005

Ou R, Zhou S, Huang L, Moskophidis D, J. Virol. 75, 8407-8423, 2001. http://dx.doi.org/10.1128/JVI.75.18.8407-8423.2001

Palacios G, Druce J, Du L, Tran T, Birch C, Briese T, Conlan S, Quan PL, Hui J, Marshall J, Simons JF, Egholm M, Paddock CD, Shieh WJ, Goldsmith CS, Zaki SR, Catton M, Lipkin WI, N. Engl. J. Med. 358, 991-998, 2008. http:// dx.doi.org/10.1056/NEJMoa073785

Peng T, Zhu J, Hwangbo Y, Corey L, Bumgarner RE, J. Virol. 82, 19341945, 2008. http://dx.doi.org/10.1128/JVI.01649-07

Perry AK, Chen G, Zheng D, Tang H, Cheng G, Cell Res. 15, 407-22, 2005. http://dx.doi.org/10.1038/sj.cr.7290309

Pestka S, Krause CD, Walter MR, Immunol. Rev. 202, 8-32, 2004. http://dx.doi.org/10.1111/j.0105-2896.2004.00204.x

Peters CJ, Curr. Microbiol. Immunol. 262, 65-74, 2002. http:// dx.doi.org/10.1007/978-3-642-56029-3 3

Pirhonen J, Sareneva T, Kurimoto M, Julkunen I, Matikainen S, J. Immunol. 162, 7322-7329, 1999.

Pirhonen J, Matikainen S, Julkunen I, J. Immunol. 169, 5673-5678, 2002.

Pitha PM, Interferon: The 50th Anniversary. Springer Berlin Heidelberg, New York, p. 24. ISBN 978-3-540-71328-9, 2007. http://dx.doi.org/10.1007/978-3-540-71329-6

Pythoud C, Rodrigo WW, Pasqual G, Rothenberger S, MartinezSobrido L, de la Torre JC, Kunz S, J. Virol. 86, 7728-7738, 2012. http://dx.doi.org/10.1128/JVI.00187-12

Robek MD, Boyd BS, Chisari FV, J. Virol. 79, 3851-3854, 2005. http://dx.doi.org/10.1128/JVI.79.6.3851-3854.2005

Rodrigo WW, Ortiz-Riano E, Pythoud C, Kunz S, de la Torre JC, Martinez-Sobrido L J. Virol. 86, 8185-8197, 2012. http:// dx.doi.org/10.1128/JVI.07240-11

Ronni T, Sareneva T, Pirhonen J, Julkunen I, J. Immunol. 154, 2764-2774, 1995.
Sareneva T, Matikainen S, Kurimoto M, Julkunen I, J. Immunol. 160, 6032-6038, 1998.

Sareneva T, Julkunen I, Matikainen S, J. Immunol. 165, 1933-1938, 2000.

Schroder K, Hertzog PJ, Ravasi T, Hume DA, J. Leukoc. Biol. 75, 163-89, 2004. http://dx.doi.org/10.1189/jlb.0603252

Saron MF, Riviere Y, Hovanessian AG, Guillon JC, Virology 117, 253256, 1982. http://dx.doi.org/10.1016/0042-6822(82)90524-4

Sheppard P, Kindsvogel W, Xu W, Henderson K, Schlutsmeyer S, Whitmore TE, Kuestner R, Garrigues U, Birks C, Roraback J, Ostrander C, Dong D, Shin J, Presnell S, Fox B, Haldeman B, Cooper E, Taft D, Gilbert T, Grant FJ, Tackett M, Krivan W, McKnight G, Clegg C, Foster D, Klucher KM, Nat. Immunol., 4, 63-68, 2003. http://dx.doi. org/10.1038/ni873

Sommereyns C, Paul S, Staeheli P, Michiels T, PLoS Pathog. 4, e1000017, 2008. http://dx.doi.org/10.1371/journal. ppat. 1000017

Sutejo R, Yeo DS, Myaing MZ, Hui C, Xia J, Ko D, Cheung PC, Tan BH, Sugrue RJ, PLoS One 7, e33732, 2012. http://dx.doi. org/10.1371/journal.pone.0033732

Svetliková D, Kabát P, Ohradanová A, Pastorek J, Betaková T, Antiviral Res. 88, 329-333, 2010. http://dx.doi.org/10.1016/j. antiviral.2010.10.005

Tong S, Li Y, Rivailler P, Conrardy C, Castillo DA, Chen LM, Recuenco S, Ellison JA, Davis CT, York IA, Turmelle AS, Moran D, Rogers S, Shi M, Tao Y, Weil MR, Tang K, Rowe LA, Sammons S, Xu X, Frace M, Lindblade KA, Cox NJ, Anderson LJ, Rupprecht CE, Donis RO, Proc. Natl. Acad. Sci. USA 109, 4269-4274, 2012. Szpara ML, Kobiler O, Enquist LW, J. Neuroimmune Pharmacol. 5, 418-427, 2010. http://dx.doi.org/10.1007/s11481010-9212-0

Uzé G, Monneron D, Biochimie 89, 729-734, 2007. http://dx.doi. org/10.1016/j.biochi.2007.01.008

Wang J, Oberley-Deegan R, Wang S, Nikrad M, Funk CJ, Hartshorn KL, Mason RJ, J. Immunol. 182, 1296-1304, 2009.

Welsh R, In Mahy BWJ, van Regenmortel, MHV (Ed.): Encyclopedia of Virology, Academic Press Amsterdam; Boston, pp. 238-243, 2008. http://dx.doi.org/10.1016/B978012374410-4.00439-8

Wise HM, Foeglein A, Sun J, Dalton RM, Patel S, Howard W, Anderson EC, Barclay WS, Digard P, J. Virol. 83, 8021-8031, 2009. http://dx.doi.org/10.1128/JVI.00826-09

Witte K, Gruetz G, Volk HD, Looman AC, Asadullah K, Sterry W, Sabat R, Wolk K, Genes Immun. 10, 702-714, 2009. http:// dx.doi.org/10.1038/gene.2009.72

Yeldandi AV, Colby TV, Hum. Pathol. 25, 47-53, 1994. http://dx.doi. org/10.1016/0046-8177(94)90170-8

Zhou S, Cerny AM, Zacharia A, Fitzgerald KA, Kurt-Jones EA, Finberg RW, J. Virol. 84, 9452-9462, 2010. http://dx.doi. org/10.1128/JVI.00155-10

Zhou Z, Hamming OJ, Ank N, Paludan SR, Nielsen AL, Hartmann R, J. Virol. 81, 7749-7758, 2007. http://dx.doi.org/10.1128/ JVI.02438-06

Zinkernagel RM, Curr. Top. Microbiol. Immunol. 263, 1-5, 2002 http://dx.doi.org/10.1007/978-3-642-56055-2 1 